(c) Group of authors, 2019

UDC 616.13-004.6

DOI - https://doi.org/10.14300/mnnc.2019.14108

ISSN - 2073-8137

\title{
CORRECTIVE EFFECT OF ANGIOTENSIN-CONVERTING ENZYME INHIBITORS ON THE DAILY PROFILE OF BLOOD PRESSURE AND SOMNOLOGICAL CHARACTERISTICS IN ELDERLY PATIENTS WITH COMBINED CARDIAC PATHOLOGY
}

\author{
Osadchuk M. A., Vasil'eva I. N., Mironova E. D., Khudarova A. A., Korzhenkov N. P.
}

First Sechenov Moscow State Medical University (Sechenov University), Russian Federation

\section{КОРРИГИРУЮЩЕЕ ВАИЯНИЕ ИНГИБИТОРОВ АНГИОТЕНЗИНПРЕВРАЩАЮЩЕГО ФЕРМЕНТА НА СУТОЧНЫЙ ПРОФИАЬ АРТЕРИААЬНОГО ААВАЕНИЯ И СОМНОАОГИЧЕСКИЕ ХАРАКТЕРИСТИКИ У ПАЦИЕНТОВ ПОЖИАОГО ВОЗРАСТА С СОЧЕТАННОЙ КАРАИААЬНОЙ ПАТОАОГИЕЙ}

\author{
М. А. ОсаАчук, И. Н. Васильева, Е. А. Миронова, А. А. ХуАарова, Н. П. Корженков \\ Первый Московский госуАарственный меАицинский университет \\ им. И. М. Сеченова (Сеченовский Университет), Российская ФеАерация
}

In recent years, a particular approach to the treatment of elderly patients with combined cardiac pathology has been gaining importance. It is aimed at adequate antihypertensive therapy and correction of chronologically occurring circadian biorhythms to study the curative effect of ramipril on the daily blood pressure (BP) profile and somnological characteristics of elderly patients with arterial hypertension $(\mathrm{AH})$ and coronary artery disease (CAD). In an outpatient setting, 57 patients with the $1^{\text {st }}$ and $2^{\text {nd }}$ degree of stage III essential AH in combination with angina pectoris (AP) 1 and 2 functional class (FC) were examined. Patients underwent general clinical, laboratory examination, daily monitoring of blood pressure, somnological questionnaire survey. The study results allowed us to conclude that ramipril has a significant corrective effect on the regular BP profile and somnological characteristics in patients with combined cardiac pathology.

Keywords: arterial hypertension, coronary artery disease, daily blood pressure profile, circadian biorhythms, somnological disorders

В последние годы важное значение приобретает подход к лечению пациентов пожилого возраста с сочетанной кардиальной патологией, направленный на адекватную антигипертензивную терапию и коррекцию хронологически протекающих циркадных биоритмов. В проведенном исследовании изучалось влияние рамиприла на суточный профиль артериального давления и сомнологические характеристики пациентов пожилого возраста с артериальной гипертензией и ишемической болезнью сердца. В амбулаторно-поликлинических условиях обследовано 57 пациентов с эссенциальной артериальной гипертензией III стадии 1-й и 2-й степени в сочетании со стенокардией напряжения 1-го и 2-го ФК. Пациентам проводили общеклиническое, лабораторное обследование, суточное мониторирование артериального давления, анкетирование по сомнологическим опросникам. Результаты позволили сделать заключение о значимом корригирующем влиянии рамиприла на суточный профиль артериального давления и сомнологические характеристики у больных с сочетанной кардиальной патологией.

Ключевые слова: артериальная гипертензия, ишемическая болезнь сердца, суточный профиль артериального давления, циркадные биоритмы, сомнологические нарушения

For citation: Osadchuk M. A., Vasil'eva I. N., Mironova E. D., Khudarova A. A., Korzhenkov N. P. CORRECTIVE EFFECT OF ANGIOTENSIN-CONVERTING ENZYME INHIBITORS ON THE DAILY PROFILE OF BLOOD PRESSURE AND SOMNOLOGICAL CHARACTERISTICS IN ELDERLY PATIENTS WITH COMBINED CARDIAC PATHOLOGY. Medical News of North Caucasus. 2019;14(3):448-453. DOI - https://doi.org/10.14300/mnnc.2019.14108

Для цитирования: Осадчук М. А., Васильева И. Н., Миронова Е. Д., Хударова А. А., Корженков Н. П. КОРРИГИРУЮЩЕЕ ВЛИЯНИЕ ИНГИБИТОРОВ АНГИОТЕНЗИНПРЕВРАЩАЮЩЕГО ФЕРМЕНТА НА СУТОЧНЫЙ ПРОФИЛЬ АРТЕРИАЛЬНОГО ДАВЛЕНИЯ И СОМНОЛОГИЧЕСКИЕ ХАРАКТЕРИСТИКИ У ПАЦИЕНТОВ ПОЖИЛОГО ВОЗРАСТА С СОЧЕТАННОЙ КАРДИАЛЬНОЙ ПАТОЛОГИЕЙ. МедицинСКИЙ вестник Северного Кавказа. 2019;14(3):448-453.

DOI - https://doi.org/10.14300/mnnc.2019.14108 


\begin{tabular}{|c|c|c|c|}
\hline ABMP & - daily (ambulatory) of blood pressure monitoring & HBI & - hyperbaric index \\
\hline \multicolumn{2}{|c|}{ ABMP profile- daily blood pressure monitoring profile } & HR & - heart rate \\
\hline ACE & - inhibitor angiotensin-converting enzyme & HRV & - heart rate variability \\
\hline $\mathrm{AH}$ & - arterial hypertension & ISI & - insomnia severity index \\
\hline$A P$ & - angina pectoris & MBPRS & - morning blood pressure rise speed \\
\hline $\mathrm{BP}$ & - blood pressure & MBPSI & - morning BP speed index \\
\hline BP load & - Blood Pressure Load & MBPSI of SBP & - morning BP speed index \\
\hline CAD & - coronary artery disease & $\mathrm{MH}$ & - morning hypertension \\
\hline $\mathrm{CHF}$ & - chronic heart failure & MI & - myocardial infarction \\
\hline CVD & - cardiovascular disease & NBP dip (dipping & - the degree of nocturnal blood pressure \\
\hline DBP & - diastolic blood pressure & & decrease \\
\hline DBPV & - diastolic blood pressure variability & PBP & - pulse blood pressure \\
\hline FC & - functional class & SBP & - systolic blood pressure \\
\hline GBI & - hyperbaric index & SBPV & - systolic blood pressure variability \\
\hline HAI & - hypertension area index & & \\
\hline
\end{tabular}

\section{C} ardiovascular disease (CVD), dominant in the structure of morbidity and general mortality worldwide, is the subject of global health close attention. The practical importance of studying this problem is also due to combined cardiac pathology high prevalence, among which the leading positions belong to CAD and $A H$ [1]. Factors unity contributing to the occurrence of both CAD and $A H$ indicates a certain similarity in their development, despite different time intervals from the factor's onset to their influence manifestation [2]. Besides, these diseases unifying aspect is the isomorphism of the pathogenetic process various parts, whose study in recent years has been the subject of many works [3].

An increase in the tone of the sympathetic nervous system and activation of the hypothalamic-pituitaryadrenal systems in patients with $A H$ and CAD is manifested by circadian biorhythms desynchronosis, which contributes to somnological disorder development [4]. Moreover, chronic sleep disorders can significantly aggravate the CVD course [5]. In this regard, an individual approach to cardiac patients' treatment is gaining importance, aimed not only at compensating for the underlying disease, but also correcting circadian biorhythms.

Of course, a significant pharmacological revolution occurred in the 70s. XX century, when a group of scientists led by D. W. Cushman and M. A. Ondetti synthesized the first inhibitor of the angiotensin-converting enzyme (ACE inhibitor) - captopril. This event mainly influenced the further evolution of views on this class representatives' role in CVD treatment. For a long time, the only indication for ACE inhibitors use was hypertension. Subsequently, the first randomized CAPPP (The Captopril Prevention Project) test demonstrated the effective captopril ability to influence the reduction in complications and mortality frequency in patients with hypertension [6].

Later the results of numerous studies presented not only useful antihypertensive qualities of this drug group but also proved its beneficial effect on cardiovascular continuum in general. Thus, the GISSI study had an ACE inhibitors positive effect on the prognosis of patients with acute myocardial infarction (MI) by reducing mortality while taking lisinopril [7]. The SMILE study results showed reducing mortality and the risk of developing chronic heart failure $(\mathrm{CHF})$ in $\mathrm{Ml}$ patients zofenopril treatment. The SMILE-4 study result was a standardized death rate decrease in men over 76 with chronic heart failure when taking this drug [8]. Over time, the prognostic effect on cardiovascular outcomes in patients with CVD has been proven for other ACE inhibitors [9-11]. And no one doubts that ACE inhibitors are deservedly the first-line drugs in the treatment and prevention of socially significant diseases, which, of course, include $\mathrm{CHF}, \mathrm{AH}$, and CAD.
In the Russian guidelines for the management of patients with stable angina, perindopril and ramipril are preferred as drugs with proven anti-ischemic efficacy [12]. Ramipril, having the ability to influence all cardiovascular continuum parts and prevent cardiovascular complication development, significantly reduces death risk in both young [13] and older people [14]. Based on this, ACE inhibitors should be considered the essential component of the complex therapy of patients with combined cardiac pathology, regardless of age. Because of the preceding, this study aimed to study the corrective effect of ramipril on the daily blood pressure profile (ABMP), its circadian biorhythms, and somnological characteristics in elderly patients with a combination of $\mathrm{AH}$ and $\mathrm{CAD}$.

Material and Methods. On an outpatient basis, 57 elderly patients with the $1^{\text {st }}$ and $2^{\text {nd }}$ degree of stage III essential $\mathrm{AH}$ in combination with CAD were examined (19 men, 38 women; average age - 70.6 \pm 7.2 years). Most patients $(86.6 \%)$ had the $2^{\text {nd }} A P$ FC, and $7.5 \%$ of patients had an MI history. The average duration of hypertension was $9.3 \pm 1.7$ years and coronary heart disease $-4.6 \pm 1.1$ years

Exclusion criteria: patients with symptomatic $\mathrm{AH}$, grade III AH, unstable AP, valvular heart disease, MI or stroke for less than six months, severe rhythm disturbances, and decompensated concomitant diseases.

In addition to general clinical and laboratory examination, all patients underwent 24-hour blood pressure monitoring (ABPM) with the use of the BPLab complex of hardware-software BP monitoring (Russia). The study results assessment was carried out, taking into account the ABPM parameters linear analysis in consent with European recommendations [15]. The mean, maximum, and minimum systolic BP (SBP) and diastolic $\mathrm{BP}(\mathrm{DBP})$ values, their variability, and pulse BP (PBP) per day were determined. Quantitative assessment of the «pressure load» value was carried out by the BP load, hyperbaric index ( $\mathrm{HBI})$. Given the available biphasic daily fluctuations in all patients ' BP, the degree of nocturnal BP decrease (NBP dip) was evaluated. Its maximum values determined the standard parameters of the morning $\mathrm{BP}$ rise in the morning hours, morning hypertension $(\mathrm{MH})$ values, it's rate, as well as the combined «index of morning hours» (MBPSI). Daily ECG monitoring (ECG $D M)$ was performed for 24 hours when antianginal drugs had been canceled a day before the study using a BTL08 ECG HOLTER electrocardiograph (Great Britain). The number of myocardial ischemia episodes with STsegment deviation and their average duration was taken into account. To identify possible sleep disorders, the somnological questionnaire "Subjective assessment of sleep characteristics» (A. M. Wayne, Y. I. Levin) was used [16]; somnological disorders severity was assessed using the «Insomnia Severity Index» (ISI) (C. Morin) [17]. 
According to the clinical recommendations for stable AP diagnosis and treatment [12], all patients were prescribed standard-essential therapy, including acetylsalicylic acid (class I recommendations with evidence level A), atorvastatin (class I, level A) at an average dose of $15.8 \pm 0.6 \mathrm{mg} /$ day and metoprolol succinate (class I, level A) at a dose of $50.4 \pm 11.6 \mathrm{mg} /$ day.

The preliminary treatment results were evaluated after two weeks. The criterion for the anti-ischemic therapy effectiveness was a reduction in the frequency of angina attacks per week and the patient's need for nitroglycerin. The criterion of antihypertensive therapy efficacy was a decrease in blood pressure (office) $<140 / 90 \mathrm{~mm} \mathrm{Hg}$, and more from the initial level. The criterion of blood pressure normalization in people of the older age group (from 65 to 79 years) was the SBP level of up to $130-139 \mathrm{~mm} \mathrm{Hg}$. (with good tolerance not $<120 \mathrm{~mm} \mathrm{Hg}$ ), and the DBP level of up to $70-79 \mathrm{~mm} \mathrm{Hg}$. In the absence of the desired effect, patients who did not have significant improvement within two weeks $(n=41)$ were divided into two groups using random selection. Patients of the $1^{\text {st }}$ group $(n=21)$ continued essential therapy with an increase in the dose of $\beta$-blocker to the maximum tolerated $(61.8 \pm 12.5 \mathrm{mg} /$ day). In patients of the $2^{\text {nd }}$ group $(n=20)$, the ACE inhibitor ramipril was added to the particular treatment regimen (average dose of $7.9 \pm 1.8 \mathrm{mg} /$ day). Patients dynamic monitoring was carried out over ten weeks.

The results of statistical processing were carried out using STATISTICA 10.0 (StatSoft, USA). When performing the calculations, standard descriptive statistics methods were used; the mean value $(\mathrm{M})$ and the standard deviation (SD) were estimated. Quantitative values were presented in the form of a record $M \pm S D$ with indicating frequency and percentage. Taking into account the available sample of a small volume, nonparametric statistical methods were used. The reliability of the indicators' dynamics was assessed using the Wilcoxon test, intergroup differences according to the $\chi^{2}$ criterion. The probability value $p<0.05$ testified to statistical significance.

Results and Discussion. According to the results obtained, after 10 weeks regular treatment, an improvement in the clinical status of both groups representatives was observed, as evidenced by changes in the AP FC of individuals participating in the study. In the $1^{\text {st }}$ comparison group, the number of patients with FC I AP increased by $39.9 \%$ (from $28.6 \%$ to $47.6 \%$; $p=0.06$ ), the duration of ST segment depression according to the Holter ECG decreased to $1.3 \pm 0.08 \min (\Delta=-35.6 \%$; $p=0.09)$, the need for nitroglycerin decreased from $2.39 \pm 0.19$ to $1.25 \pm 0.17$ per week $(\Delta=-47.7 \% ; p=0.03)$. In representatives of the $2^{\text {nd }}$ group, the dynamics was more pronounced. The number of patients with FC I AP increased to $60.0 \%(\Delta=-58.3 \% ; p=0.04)$, the duration of ST segment deviation was reduced to $1.2 \pm 0.03 \mathrm{~min}(\Delta=-44.6 \%$; $p=0.06$ ), and the application frequency of short-acting nitrates per week - from $2.37 \pm 0,22$ to $0.94 \pm 0.14$ $(\Delta=-60.3 \% ; p=0.01)$.

By the end of the observation period clinical blood pressure studies had showed a significant decrease in representatives of all SPB and DBP groups. In patients of the $1^{\text {st }}$ group, SBP (office) decreased by $9.7 \%$ (from $150.1 \pm 3.8$ to $135.5 \pm 2.7 \mathrm{~mm} \mathrm{Hg} ; \mathrm{p}=0.001$ ), $\mathrm{DBP}$ - by $9.4 \%$ (from $89.3 \pm 2.0$ to $80.9 \pm 1.7 \mathrm{~mm} \mathrm{Hg} ; p=0.001$ ), while in persons of the $2^{\text {nd }}$ group - by $16.1 \%$ (from $150.6 \pm 5.1$ to $126.3 \pm 2.1 ; p=0.0001$ ) and $15.0 \%$ (from $90.3 \pm 1.8$ to $76.8 \pm 1.5 \mathrm{~mm} \mathrm{Hg} ; p=0.0001)$, respectively. $47.6 \%(n=10)$ of the $1^{\text {st }}$ group patients and $71.4 \%(n=15)$ of the $2^{\text {nd }}$ group ones, who took ramipril, reached the target blood pressure values.

A statistically significant decrease in the daily ambulatory $\mathrm{BP}$ monitoring (ABPM) values detected in patients of both groups, regardless of the chosen therapy, indicated a reduction in pressor load during treatment (Table 1). However, ramipril therapy was accompanied by significant dynamics in pressure loading parameters (according to the $\chi^{2}$ criterion; $\mathrm{p}<0.05$ ), thereby providing a significant contribution to the positive prognosis of patients with high cardiovascular risk.

Table 1

ABMP indicators` dynamics during therapy

\begin{tabular}{|c|c|c|c|c|c|c|c|c|}
\hline \multirow{2}{*}{ Indicators } & \multicolumn{4}{|c|}{$1^{\text {st }}$ group $(n=21)$} & \multicolumn{4}{|c|}{$2^{\text {nd }}$ group $(n=20)$} \\
\hline & Initially & After 10 weeks & $\mathrm{p}$ & $\Delta$ & Initially & After 10 weeks & $p$ & $\Delta$ \\
\hline Daily SBP, mm Hg & $143.9 \pm 2.5$ & $131.6 \pm 2.7$ & 0.003 & $-9.0 \%$ & $143.8 \pm 4.5$ & $123.7 \pm 2.2$ & 0.0001 & $-14.0 \%$ \\
\hline Daily DBP, mm Hg & $87.2 \pm 1.8$ & $78.4 \pm 1.5$ & 0.003 & $-10.1 \%$ & $89.9 \pm 1.5$ & $76.6 \pm 1.1$ & 0.004 & $-14.8 \%$ \\
\hline Daily $\mathrm{HR}$, beats/min & $74.8 \pm 2.2$ & $64.5 \pm 1.4$ & 0.001 & $-13.7 \%$ & $72.9 \pm 1.8$ & $63.9 \pm 1.3$ & 0.0001 & $-12.3 \%$ \\
\hline Daily PBP, $\mathrm{mm} \mathrm{Hg}$ & $59.8 \pm 1.3$ & $=2.1$ & 0.004 & $-11.2 \%$ & $61.2 \pm 2.0$ & $1.9 \pm 1.4$ & .0003 & $.2 \%$ \\
\hline Mean daily $\mathrm{BP}, \mathrm{mm} \mathrm{Hg}$ & $104.7 \pm 2.7$ & $96.3 \pm 2.1$ & 0.03 & $-8.6 \%$ & $105.9 \pm 2.6$ & $94.7 \pm 1.4$ & 0.001 & $-10.6 \%$ \\
\hline Daily SBPV, $\mathrm{mm} \mathrm{Hg}$ & $15.9 \pm 0.8$ & \pm 0.7 & $\mathrm{n} / \mathrm{d}$ & $-11.6 \%$ & $16.2 \pm 0.8$ & 0.6 & 0.06 & $-13.1 \%$ \\
\hline Diurnal SBPV, mm HG & $16.0 \pm 0.7$ & $14.1 \pm 1.0$ & $\mathrm{n} / \mathrm{d}$ & $-11.8 \%$ & $16.1 \pm 0.9$ & $14.2 \pm 0.7$ & $n / d$ & $-11.8 \%$ \\
\hline Nocturnal SBPV, mm Hg & 0.8 & .9 & $\mathrm{n} / \mathrm{d}$ & $-11.4 \%$ & 1.0 & & 0.09 & $-13.9 \%$ \\
\hline Daily DBPV, $\mathrm{mm} \mathrm{Hg}$ & $13.3 \pm 0.6$ & $12.2 \pm 0.4$ & $\mathrm{n} / \mathrm{d}$ & $-8.3 \%$ & $13.1 \pm 0.7$ & 11 & $\mathrm{n} / \mathrm{d}$ & $-13.7 \%$ \\
\hline Daily HRV, beats/min & 1.0 & 0.2 & 0.04 & $-18.0 \%$ & 0.9 & 6 & 0.04 & $.9 \%$ \\
\hline Daily HBI of SBP, \% & $239.2 \pm 34.6$ & $189.2 \pm 28.2$ & 0.001 & $-20.9 \%$ & $240.5 \pm 36.9$ & $159.0 \pm 39.7$ & 0.0003 & $-33.9 \%$ \\
\hline Daily HBI of DBP, \% & $102.0 \pm 33.5$ & $83.8 \pm 12.4$ & 0.003 & $-17.8 \%$ & $103.2 \pm 24.6$ & $64.4 \pm 9.8$ & 0.0001 & $-37.6 \%$ \\
\hline Daily BP load of SBP, \% & $69.6 \pm 5.3$ & $46.1 \pm 6.2$ & 0.001 & $-33.7 \%$ & $70.4 \pm 4.2$ & $36.9 \pm 3.6$ & 0.001 & $-47.6 \%$ \\
\hline Daily BP load of DBP, \% & $56.7 \pm 5.2$ & $40.4 \pm 5.8$ & 0.05 & $-28.7 \%$ & $56.9 \pm 5.3$ & $30.1 \pm 3.9$ & 0.001 & $-47.1 \%$ \\
\hline MBPSI of SBP, $\mathrm{mm} \mathrm{Hg} / \mathrm{min}^{2}$ & $895.7 \pm 92.2$ & $739.5 \pm 85.9$ & 0.04 & $-17.4 \%$ & $894.0 \pm 102.1$ & $608.2 \pm 96.4$ & 0.002 & $-32.0 \%$ \\
\hline MBPSI of DBP, $\mathrm{mm} \mathrm{Hg} / \mathrm{min}^{2}$ & $414.5 \pm 69.7$ & $326.6 \pm 65.4$ & 0.03 & $-21.2 \%$ & $415.5 \pm 67.3$ & $299.8 \pm 62.2$ & 0.003 & $-27.8 \%$ \\
\hline a.m. SBP rise, $\mathrm{mm} \mathrm{Hg}$ & $50.3 \pm 4.5$ & $43.3 \pm 2.6$ & 0.04 & $-13.9 \%$ & $50.3 \pm 3.9$ & $39.8 \pm 3.1$ & 0.04 & $-20.9 \%$ \\
\hline a.m. DBP rise, $\mathrm{mm} \mathrm{Hg}$ & $35.6 \pm 2.7$ & $33.8 \pm 2.0$ & $\mathrm{n} / \mathrm{d}$ & $-5.1 \%$ & $35.4 \pm 2.8$ & $30.2 \pm 2.9$ & $\mathrm{n} / \mathrm{d}$ & $-14.7 \%$ \\
\hline a.m. SBP rise rate, $\mathrm{mm} \mathrm{Hg}$ & $19.1 \pm 1.2$ & $16.2 \pm 0.9$ & 0.03 & $-15.2 \%$ & $19.1 \pm 1.8$ & $14.1 \pm 0.9$ & 0.01 & $-26.2 \%$ \\
\hline a.m. DBP rise rate, $\mathrm{mm} \mathrm{Hg}$ & $19.6 \pm 2.1$ & $17.2 \pm 1.8$ & $\mathrm{n} / \mathrm{d}$ & $-12.2 \%$ & $19.4 \pm 2.3$ & $15.2 \pm 1.6$ & 0.01 & $-21.6 \%$ \\
\hline
\end{tabular}

Note. The data are presented in $\mathrm{M} \pm \mathrm{SD} ; \Delta$ and $\mathrm{p}$ are indicated in comparison with the initial data. 
The pulse blood pressure (PBP) role in CVD development being determined, its exceeded value, initially found in all patients, indicated vascular wall rigidity and increased hyperbaric load, as a result of the reflection wave appearance. The ramipril ability to suppress vascular endothelial cell proliferation was first demonstrated in the SECURE study [18], whose results showed a $37 \%$ slower atherosclerosis progression when using ramipril. Later, the AIREX study revealed ACE inhibitors' ability to reduce cardiovascular complications and standardized death rate indicators $(\Delta=-36,0 \%)$ through its angioprotective property [19]. Therefore, patients with an initially high PBP should be prescribed pathogenesis-based therapy affecting systemic hemodynamics parameters to improve their prognosis.

Due to elderly patients impaired regulatory mechanisms, special attention was also given to the highspeed BP characteristics the magnitude and speed of the morning rise. It is known that $\mathrm{MH}$ is an integral indicator, which depends primarily on the BP increase time and magnitude, and neither BP daily rhythm nor its mean values have an effect on it. Therefore, the correlation between the morning BP rise and the variability of the mean daily SBP, DBP, PBP values, and myocardial mass index [20], established in some studies, is surprising. The $\mathrm{MH}$ in both groups had upper threshold values; the morning BP rise speed significantly exceeded the normative limit. And only in patients of the $2^{\text {nd }}$ group taking ramipril, by the end of the observation period, the speed and magnitude of the morning BP rise had significantly decreased $(p<0.05)$.

Taking into account cardiovascular events increase in the early hours, we also considered the positive dynamics of the combined integral morning hours index as a criterion for normalizing BP during the therapy course: morning BP rise speed index (MBPRSI) $=\mathrm{d} /$ $\mathrm{dt}(\mathrm{BP}) \times \mathrm{BP} \times$ heart rate $(\mathrm{mm} \mathrm{Hg}) 2 \times \mathrm{min}-2)$. It should be noted that in both comparison groups there was a significant change in this indicator values, more significant for patients of the $2^{\text {nd }}$ group (with intergroup comparison $\Delta=-32.0 \% ; \mathrm{p}<0.05)$, which showed ACE inhibitors corrective effect on morning risk factors cardiovascular complications, as well as sleep quality characteristics.

The successful tactics of treating patients with $\mathrm{AH}$ and CAD lie in its ability to influence the regular physiological circadian activity of neurohumoral systems, thereby forming an entirely new - chronobiological - approach to the treatment of patients with high cardiovascular risk. It is known that several neurohumoral systems are involved in BP circadian rhythm formation, which determines the synchronized blood pressure fluctuations pattern during the day [21]. The circadian body rhythms mismatched with the environmental ones are called external desynchronosis, which occurs even in a healthy person (during air travel). Internal desynchronosis manifests itself in a violation of the natural relationships between various body systems' daily biorhythms. As described by B. S. Alyakrinsky, it is observed in multiple diseases and involutive states [22]. Therefore, special importance was attached to the analysis of the circadian BP rhythm according to the dynamics of the NBP dip (Table 2). The positive therapy effect on blood pressure variations was determined mainly by the transition of «non-dipper» and «night-peaker» to the «dipper» group, whose number increased to $75.0 \%$ in the $2^{\text {nd }}$ group $(p<0.05)$. A detailed ABMP profile analysis revealed a high prevalence of pathological blood pressure profiles in older women (22 people), which indicates a more significant internal circadian biorhythms desynchronosis and explains the higher incidence of various sleep disorders in them compared to men.

Table 2 in patients of both groups during therapy \begin{tabular}{|c|c}
$1^{\text {st }}$ group & $2^{\text {nd }}$ group
\end{tabular} $(n=21) \quad(n=20)$

\begin{tabular}{|c|c|c|c|c|c|} 
Initially & $10^{\text {th }}$ week & $\mathrm{p}$ & Initially & $10^{\text {th }}$ week & $\mathrm{p}$ \\
\hline
\end{tabular}

\begin{tabular}{l|l|l|l|}
38.1 & 57.1 & 0.04 & 30.0 \\
\hline 33.3 & 23.8 & 0.07 & 50.0
\end{tabular}

\begin{tabular}{c|c|c|}
\hline 33.3 & 23.8 & 0.07 \\
\hline 4.8 & 4.8 & 1.0
\end{tabular}

50.0

25.0

\begin{tabular}{l|l|l|l|}
23.8 & 14.3 & 0.046 & 20.0 \\
\hline
\end{tabular}

\begin{tabular}{c|c}
0 & 0 \\
\hline 20.0 & 15.0
\end{tabular}

\begin{tabular}{l|l|l|}
47.6 & 66.7 & 0.02 \\
\hline
\end{tabular}

\begin{tabular}{|c|c|c|c|c|c|}
\hline 42.9 & 28.5 & 0.04 & 40.0 & 15.0 & 0.03 \\
\hline 0 & 0 & 1.0 & 5.0 & 5.0 & 1.0 \\
\hline 9.5 & 4.8 & 0.8 & 10.0 & 5.0 & 0.7 \\
\hline $2 \pm 0.03$ & $1.24 \pm 0.02$ & 0.12 & $1.21 \pm 0.03$ & $1.24 \pm 0.03$ & 0.09 \\
\hline
\end{tabular}

nted in $\%$ and $M \pm S D$.

Recent studies show the connection of circadian biological rhythms desynchronosis and sleep disorders with various psychosomatic diseases [23]. Besides, night rest duration decreases to 5 hours a day or less causes an increase in mortality, especially in people of an older age group. The most common type of sleep disturbance is insomnia - a syndrome characterized by impaired initiation, duration, and consolidation of sleep resulting in impaired daily activities. Insomnia is associated with numerous social and medical consequences and is widespread in the general population [24]. According to A. V. Golenkov and M. G. Poluektov's research results, the frequency of sleep disorders that occur in the elderly and senile in the Russian Federation, reaches $32.9 \%$ [25]. The initial questionnaire of patients who took part in the study showed various sleep disorders high incidence (70.7\%), despite the sufficient duration of its total time (8.32 \pm 1.74 hours). Borderline sleep changes ( $\geq 19$ points) were detected in $31.0 \%$ of patients, and signs of severe insomnia (<less than 19 points) were detected in $69.0 \%$. Elderly patients with a combination of $\mathrm{AH}$ and CAD most often had difficulty falling asleep (53.7 \%), too early morning awakening $(48.8 \%)$, respiratory failure in sleep (34.5\%), and coughing with interruption $(31.0 \%)$. With BP daily profile normalization during therapy, subjective sleep characteristics improved, especially in patients taking ACE inhibitors (Table 3): the time to fall asleep decreased $(\Delta=-19.4 \% ; p=0.001)$, morning awakening quality improved $(\Delta=-24.2 \% ; \mathrm{p}=0.001)$. Also, ramipril therapy effectiveness was manifested by a statistically significant decrease in insomnia severity index by $22.3 \%(p=0.04)$ and by $19.0 \%(p=0.03)$ 
overall assessment dynamics of subjective sleep characteristics, which can be explained by daily rhythm and blood pressure profile synchronization with ramipril.

Table 3

Subjective assessment dynamics of sleep characteristics and Insomnia Severity Index during therapy on somnological questionnaires

\begin{tabular}{|l|c|c|c|c|}
\hline \multirow{2}{*}{ Analyzed parameters, score } & \multicolumn{2}{|c|}{$1^{\text {st }}$ group $(\mathrm{n}=21)$} & \multicolumn{2}{c|}{$2^{\text {nd }}$ group $(\mathrm{n}=20)$} \\
\cline { 2 - 5 } & Initially & After 10 weeks & Initially & After 10 weeks \\
\hline Time of falling to sleep & $2.6 \pm 0.8$ & $2.9 \pm 0.5^{*}$ & $2.5 \pm 0.7$ & $3.1 \pm 0.5^{*}$ \\
\hline Sleep duration & $2.9 \pm 0.5$ & $3.0 \pm 0.9$ & $2.8 \pm 0.7$ & $3.1 \pm 1.0$ \\
\hline Number of awakenings & $2.9 \pm 0.7$ & $3.2 \pm 0.5^{*}$ & $2.9 \pm 0.6$ & $3.2 \pm 0.8$ \\
\hline Sleep quality & $3.0 \pm 0.9$ & $3.2 \pm 0.6$ & $3.1 \pm 0.9$ & $3.2 \pm 0.8$ \\
\hline Number of dreams & $2.5 \pm 0.5$ & $2.6 \pm 0.8$ & $2.8 \pm 0.8$ & $2.8 \pm 0.5$ \\
\hline Morning awakening quality & $3.0 \pm 0.9$ & $3.2 \pm 1.2$ & $2.9 \pm 0.9$ & $3.6 \pm 0.7^{*} \#$ \\
\hline Total score & $15.7 \pm 3.1$ & $18.0 \pm 2.5^{*}$ & $15.8 \pm 2.9$ & $19.5 \pm 3.0^{*} \#$ \\
\hline Insomnia Severity Index & $18.4 \pm 4.0$ & $16.9 \pm 3.3$ & $18.8 \pm 3.7$ & $14.6 \pm 2.6^{*}$ \\
\hline
\end{tabular}

Note: ${ }^{*}-p<0.05$ for intragroup dynamics; $\#-p<0.05$ for differences between groups 1 and 2 .

Conclusions. Thus, the results of this study made it possible to conclude a significant corrective ramipril effect on the daily BP profile and somnological characteristics in patients with $\mathrm{AH}$ in combination with CAD. Ramipril organoprotective properties allow not only to slow down $\mathrm{AH}$ and $\mathrm{CAD}$ progression, but also to implement a completely new - chronobiological - approach to the treatment of elderly patients with high CVR.

\section{Disclosures:}

The authors declare no conflict of interest.

\section{References}

1. Kelly B. B., Narula J., Fuster V. Recognizing global burden of cardiovascular disease and related chronic diseases. Mt. Sinai. J. Med. 2012;79(6):632-640. https://doi.org/10.1002/msj.21345

2. Petrie J. R., Guzik T. J., Touyz R. M. Diabetes, Hypertension, and Cardiovascular Disease: Clinical Insights and Vascular Mechanisms. Can. J. Cardiol. 2018;34(5):575584. https://doi.org/10.1016/j.cjca.2017.12.005

3. Touyz R. M., Anagnostopoulou A., De Lucca Camargo L., Montezano A. C. Novel Biosensors Reveal a Shift in the Redox Paradigm From Oxidative to Reductive Stress in Heart Disease. Circ. Res. 2016;119(9):969-971.

https://doi.org/10.1161/CIRCRESAHA.116.309854

4. Dong Y., Yang F. M. Insomnia symptoms predict both future hypertension and depression. Prev. Med. 2019;123:41-47. https://doi.org/10.1016/j.ypmed.2019.02.001

5. Madsen M. T., Huang C., Zangger G., Zwisler A. D. O., Gögenur I. Sleep Disturbances in Patients With Coronary Heart Disease: A Systematic Review. J. Clin. Sleep Med. 2019;15(3):489-504. https://doi.org/10.5664/jcsm.7684

6. Scheen A. J. Clinical study of the month. The CAPPP study: «The Captopril Prevention Project». Rev. Med. Liege. 1999;54(3):197-199.

7. Opie L. H. The new trials: AIRE, ISIS-4, and GISSI-3. Is the dossier on ACE inhibitors and myocardial infarction now complete? Cardiovasc. Drugs Ther. 1994;8(3):469-472.

8. Borghi C., Omboni S., Novo S., Vinereanu D., Ambrosio G. [et al.] Efficacy and Safety of Zofenopril Versus Ramipril in the Treatment of Myocardial Infarction and Heart Failure: A Review of the Published and Unpublished Data of the Randomized Double-Blind SMILE-4 Study. Adv. Ther. 2018; 35(5):604-618. https://doi.org/10.1007/s12325-018-0697-x

9. Torp-Pedersen C., Køber L. Effect of ACE inhibitor trandolapril on life expectancy of patients with reduced left-ventricular function after acute myocardial infarction. TRACE Study Group. Trandolapril Cardiac Evaluation Lancet. 1999;354(9172):9-12.

https://doi.org/10.1016/s0140-6736(98)09374-x

10. Bertrand M. E., Ferrari R., Remme W. J., Simoons M. L., Fox K. M. Perindopril and $\beta$-blocker for the prevention of cardiac events and mortality in stable coronary artery disease patients: A European trial on Reduction Of cardiac events with Perindopril in stable coronary Artery disease (EUROPA) subanalysis. Am. Heart J. 2015;170(6):10921098. https://doi.org/10.1016/j.ahj.2015.08.018

11. Kübler W. ACE inhibitors in heart failure: effect on mode of death. Eur. Heart J. 1997;18(1):3-4.

https://doi.org/10.1093/oxfordjournals.eurheartj.a015114
12. National Recommendations for the diagnosis and treatment of stable angina pectoris. Moscow 2009. Available at: https://scardio.ru/content/images/recommendation/rekomendacii_po_diagnostike_i_lecheniyu_stabilnoy_stenokardii.pdf. Accessed August $\overline{0} \overline{7}, 2019$.

13. Walczak-Gałęzewska M., Szulińska M., Miller-Kasprzak E., Pupek-Musialik D., Bogdański P. The effect of nebivolol and ramipril on selected biochemical parameters, arterial stiffness, and circadian profile of blood pressure in young men with primary hypertension: A 12-week prospective randomized, open-label study trial. Medicine (Baltimore). 2018;97(30):e11717. https://doi.org/10.1097/MD.0000000000011717

14. Gianni M., Bosch J., Pogue J., Probstfield J., Dagenais G. [et al.] Effect of long-term ACE-inhibitor therapy in elderly vascular disease patients. Eur. Heart J. 2007;28(11):13828. https://doi.org/ 10.1093/eurheartj/ehm017

15. Parati G., Stergiou G., O'Brien E., Asmar R., Beilin L. [et al.] European Society of Hypertension practice guidelines for ambulatory blood pressure monitoring. J. Hypertens. 2014;32(7):1359-1366.

https://doi.org/10.1097/HJH.0000000000000221

16. Vejn A. M., Levin Y. A. I. The principles of modern pharmacotherapy of insomnia. Journal of Neurology and Psychiatry. 1998:2:45-49.

17. Morin C. M., Belleville G., Bélanger L., Ivers H. The Insomnia Severity Index: psychometric indicators to detect insomnia cases and evaluate treatment response. Sleep. 2011:34(5):601-608. https://doi.org/10.1093/sleep/34.5.601

18. Lonn E., Yusuf S., Dzavik V., Doris C., Yi Q. [et al.] Effects of ramipril and vitamin $\mathrm{E}$ on atherosclerosis: the study to evaluate carotid ultrasound changes in patients treated with ramipril and vitamin E (SECURE). Circulation. 2001; 103(7): 919-925. https://doi.org/10.1161/01.cir.103.7.919

19. Hall A. S., Murray G. D., Ball S. G. Follow-up study of patients randomly allocated ramipril or placebo for heart failure after acute myocardial infarction: AIRE Extension (AIREX) Study. Acute Infarction Ramipril Efficacy. Lancet. 1997;349(9064):1493-1497. https://doi org/10 1016/s0140-6736(97)04442-5

20. Chazova I. E., Ratova L. G. The role of 24 -hour blood pressure monitoring in assessing the effectiveness of antihypertensive therapy (Results of 24-hour blood pressure monitoring in the CLIP-ACCORD program). Systemic hypertension. 2007;1:18-26.

21. Kuliev F. A., Agaev M. M., Gusejnova A. A. Correction of central hemodynamic disorders in patients with kidney stone disease with arterial hypertension. Cardiology. 1997;8:54-55. 
22. Alyakrinskij B. S. Problems of latent desynchronosis. Cosmic biology and aerospace medicine. 1972;1:32-37.

23. Kostenko E. V., Petrova L. V., Eneeva M. A., Kamchatnov P. R. Disorders of sleep and circadian rhythms in diseases of the cardiovascular system. Journal of Neurology and Psychiatry. S. S. Korsakova. 2015;115(3):3036. Available at: https://www.mediasphera.ru/ issues/zhurnal-nevrologii-i-psikhiatrii-im-s-s-korsakova/2015/3/541997-72982015035. Accessed August 07, 2019. https://doi.org/10.17116/jnevro20151153130-36
24. Lichstein K. L., Taylor D. J., McCrae C. S., Petrov M. E. Insomnia: epidemiology and risk factors. In Kryger M. H. Roth T., Dement W. C. (eds.) Principles and Practice of Sleep Medicine. $6^{\text {th }}$ ed. Philadelphia: «Elsevier», 2016:761768.

25. Golenkov A. V., Poluektov M. G. The prevalence of sleep disorders among residents of Chuvashia (data from a continuous questionnaire). Journal of Neurology and Psychiatry. S. S. Korsakova. 2011;111(6):64-67.

\title{
About authors:
}

Osadchuk Mikhail A., MD, PhD, DSc, Head of the Department of polyclinic therapy;

tel.: +79160712626; e-mail: osadchuk.mikhail@yandex.ru; ORCID - 0000-0003-0485-6802

Vasil'eva Inna N., MD, Associate Professor of the Department of polyclinic therapy;

tel.: +79851999214; e-mail: inniva77@mail.ru; ORCID - 0000-0001-8335-1380

Mironova Ekaterina D., Clinical resident physician of the Department of polyclinic therapy;

tel.: +79152094094; e-mail: yek.mironova1995@yandex.ru; ORCID - 0000-0003-3268-2408

Khudarova Anastasia A., Clinical resident physician of the Department of polyclinic therapy;

tel.: + 79264574345; e-mail: rude_panda@mail.ru; ORCID - 0000-0002-0689-793

Korzhenkov Nikolay $\mathrm{P}, \mathrm{MD}$, Department of polyclinic therapy;

tel.:+79154842748; e-mail: korzhenkof@mail.ru; ORCHID - 0000-0003-1702-7923

(C) Group of authors, 2019

UDC 61:616.61

DOI - https://doi.org/10.14300/mnnc.2019.14109

ISSN - 2073-8137

\section{HEART REMODELING AND QUALITY OF LIFE IN PATIENTS WITH CHRONIC KIDNEY DISEASE ON RENAL REPLACEMENT THERAPY}

\author{
Urazlina S. E., Zhdanova T. V., Zueva T. V., Kuznetcova E. V. \\ Ural State Medical University, Ekaterinburg, Russian Federation
}

\section{РЕМОАЕАИРОВАНИЕ СЕРАЦА И КАЧЕСТВО ЖИЗНИ У ПАЦИЕНТОВ С ХРОНИЧЕСКОЙ БОАЕЗНЬЮ ПОЧЕК, ПОАУЧАЮЩИХ ЗАМЕСТИТЕАЬНУЮ ПОЧЕЧНУЮ ТЕРАПИЮ}

\author{
С. Е. Уразлина, Т. В. ЖАанова, Т. В. Зуева, Е. В. Кузнецова
}

\section{Уральский госуАарственный меАицинский университет, Екатеринбург, Российская ФеАерация}

The correlation between structural and hemodynamic parameters of the heart and Quality of life (QOL) parameters have been studied in chronic kidney disease (CKD) patients on hemodialysis (HD), continuous ambulatory peritoneal dialysis (CAPD) and kidney transplant recipients (KTR). Patients were divided into three groups according to the type of RRT. CKD stage 3 patients were in the control group.

The significant correlation has been founded between the values of the myocardial mass index (LVMI), end-diastolic size (LVEDS), end-diastolic volume (LVEDV), end-systolic size (LVESS), end-systolic volume (LVESV), ejection fraction (LVEF) of the left heart ventricle and QOL among patients on RRT with minimal structural and functional changes in the heart. A negative correlation has been founded between LVMI, LVEDS, LVEDV and physical health component (PF). A decrease in LVEF, as well as an increase in LVESS and LVESV, was associated with the deterioration in both indicators of physical (PF, RP) and psychological health (SF).

Keywords: quality of life, renal replacement therapy, structural changes in the left heart ventricle

У больных с хронической болезнью почек (ХБП), находящихся на лечении гемодиализом (ГД), постоянным амбулаторным перитонеальным диализом, и у реципиентов аллотрансплантации почки (АТП) наблюдалась взаимосвязь структурных и гемодинамических показателей сердца с параметрами качества жизни (КЖ) при достигнутых целевых клинико-лабораторных значениях заместительной почечной терапии (ЗПТ). В исследование включены пациенты с ХБП 5, выделенные в подгруппы по методу ЗПТ. В контрольную группу вошли пациенты с ХБП 3.

При минимальных структурно-функциональных изменениях сердца у больных, получающих ЗПт, выявлена достоверная взаимосвязь между значениями индекса массы миокарда левого желудочка (ИММлЖ), конечно-диасто- 